\title{
The Language of Rights and the Politics of Law: Perspectives on China's Last Legal Ditch Struggle
}

\author{
Leïla Choukroune ${ }^{1}$ (D)
}

Published online: 6 October 2015

(C) The Author(s) 2015. This article is published with open access at Springerlink.com

\begin{abstract}
Since Xi Jinping has taken office in 2012, China's political repression has only but intensified so that the regime is definitively turning away from the 1990s legal reforms and the many expectations that followed in terms of rule of law and other rights fostering. In replacing these recent developments in a larger perspective including that of a "socialist harmonious society", which had already shaded a particular light on Chinese reforms, this article proposes to envisage contemporary Chinese legal culture in an evolutionary and theoretical framework. In doing so, it stresses the tensions between a language of rights now fully integrated by the Chinese citizens and the politics of law used, in a last legal ditch struggle, by the Chinese Communist Party as a tool for social stability in disciplining the people by all means including by the threat of its very legal creations. It then concludes in reflecting upon the legal culture emerging out of this great divide between the people and the State.
\end{abstract}

Keywords China $\cdot$ Law $\cdot$ State $\cdot$ Rights $\cdot$ Language

Leila Choukroune

leila.choukroune@csh-delhi.com

1 Centre for Social Sciences and Humanities (CSH), CNRS Unit 3330, New Delhi, India 
You should not be able to violate the law. We need a system of rules and regulations. (...) I think the key point is that they do not respect the workers. They say the workers only have the right to work, and no other rights. This also bears on trade union matters - the right to vote, to strike, to be elected..

A Chinese Woman Labour Activist, May 2014 (See China Labour Bulletin [1])

The leadership of the Party is the most fundamental guarantee for comprehensively moving ruling the country according to the law forward and accelerating the construction of a Socialist rule of law country.

(...)

All levels' Party organizations and leading cadres must deeply understand that safeguarding the authority of the Constitution and the laws means safeguarding the authority of the common will of the Party and the people, that defending the dignity of the Constitution and the laws is defending the dignity of the common will of the Party and the people, and that ensuring the implementation of the Constitution and the laws is the realization of the common will of the Party and the people.

CCP Central Committee Decision on Some Major Questions in Comprehensively Promoting Governing the Country.

According to Law (The original Chinese text as well as an English translation is available at: http://genius. $\mathrm{com} /$ Central-committee-of-the-chinese-communist-party-decision-of-the-fourth-plenum-of-the-18th-ccp-centralcommittee-english-annotated).

Adopted on 23rd October 2014 at the 4th Plenary Session of the 18th Central Committee of the Chinese Communist Party.

\section{Introduction}

Since Xi Jinping has taken office in 2012, China's political repression has only but intensified. With Chinese Communist Party (CCP) Central Committee publishing communiqués such as the "Document no. 9" condemning the adherence to "Western values", including constitutional democracy, the regime is definitively turning away from the 1990s legal reforms and the many expectations that followed in terms of rule of law and other rights fostering. ${ }^{1}$ At the same time, the Chinese citizens have never stopped claiming the rights they are now entitled to and seem, at best, to feign compliance with the Party's latest mantras expressed in a caricature jargon full of metaphoric clichés reminiscent of the darkest years of the Maoist era, as if the brutal waves of repressions and other attempts to discipline the people through law envisaged as an instrument of social stability were nothing but a last ditch struggle.

In replacing the recent developments in a larger historical perspective including that of a "socialist harmonious society", which had already shaded a particular light on China's reforms, this article proposes to envisage contemporary Chinese legal culture in an evolutionary and theoretical framework from rights creation (Sect. 2), and rights instrumentalisation (Sect. 3) to rights distrust (Sect. 4). In doing so, it stresses the tensions between a language of rights now fully integrated by the Chinese citizens and the politics of law used by the Chinese Communist Party as a tool for social stability in disciplining the people by all means including by the threat of its very legal creations. It then concludes in reflecting upon the legal culture emerging out of this great divide between the people and the State.

\footnotetext{
${ }^{1}$ Issued secretly in April 2013 by the General Office of the Chinese Communist Party Central Committee, the document No. 9 strikes a terrible blow against the proponents of constitutionalism in reaffirming the superiority the Party over the Constitution. As a practical example, Zhang Xuezhong, Professor at the East China College of Politics and Law, was forbidden from teaching because of his position in favour of constitutional reform. See Lubman [2].
} 


\section{Rights Creation}

China has made undeniable strides over the last 30 years of institutional and legislative reform. The constant flow of norms is impressive in terms of their vigour and the political will behind them. The legal revolutions of 1972-1982, 1992-1999 and 2001 have remade the normative landscape: adoption of a Constitution detached from its revolutionary legacy, promotion of "socialist market economy" and "socialist rule of law", accession to the World Trade Organisation (WTO) and a complete overhaul of "economic law" to bring about greater uniformity and improved legislative transparency. The constitutional amendments of 2004 carried this modernising trend further by recognising the "inviolability of private property" and stressing the State's intention to protect "human rights".

These changes in the theory and practice of Chinese law have usually been understood in terms of globalized economic relations, to which China has responded by institutionalising and internationalising its legal system, thereby contributing to the gradual emergence of a legal consciousness and a new way of relating to norms. ${ }^{3}$ In highlighting the major elements of the production and application of laws as well as some seminal developments in the creation of norms (property and labour rights), one is able to gauge the depth of this legal change enabling the development of a discourse of rights, which translation into legal actions still reveals problematic.

\subsection{Production and Application of Laws}

How are norms produced in today's China? This simple question actually deserves a rather complex answer that stresses the very limitations of the legal reforms. The National People's Congress (NPC) and the State Council are indeed the two main organs that promulgate laws in China. While the NPC and its Standing Committee are invested by the 1982 Constitution and the 2000 Legislation Law (lifa fa) with law-making power on a national scale (promulgation of "laws" or falü), the State Council has the power to adopt administrative measures (rules or guiding, regulations or tiaoli, circulars or tongzhi). The role of these two organs, however, faces broad competition from the legislative functions bestowed on other State institutions. The Chinese system operates through at least three different levels: national laws (falü), national administrative regulations (xingzheng fagui), and local administrative regulations (difangxing fagui). Moreover, ministries and commissions under the State Council can, for example, produce orders, directives and regulations in their sphere of competence and in accordance with the texts promulgated by the State Council. Local People's Congresses and their Standing Committees can also make laws, of course, as long as they do not clash with texts drawn up at the national level, all of which complicates the whole exercise. ${ }^{4}$ Finally,

\footnotetext{
${ }^{2}$ For a general appraisal of the different phases of the 1980-2000's legal reforms and before the today's reaction, see [3].

${ }^{3}$ On this and for an integrated coverage of the main aspects of Chinese judicial reform, see Lubman and Choukroune [4].

${ }^{4}$ See Chen et al. [5].
} 
the People's Congresses in the Autonomous Regions have the power to adopt their own texts. Until China's accession to the World Trade Organisation (WTO), the government did not allow external participation in the legislative process. After that, the situation has evolved and there is greater interaction with society, as shown in recent debates on the adoption of the property law. China's accession to the WTO has also encouraged the regime to publish a large number of legal texts and some court decisions; however, access to these documents requires real knowledge of the system and the Chinese language as there is no truly systematic compendium. In addition, at any step of the legislative pyramid, the Chinese Communist Party may also choose to interfere. The legislature-not exactly elected democratically, and not free from surveillance-is furthermore granted broad powers in terms of interpretation and control of the application of laws and court decisions. Despite late 1990s attempts at "constitutionalisation" of rights, the genuine superiority of the Party over the Constitution, as reiterated regularly by the CCP, poses the problem of the legitimacy of Chinese law. ${ }^{5}$ Indeed, the Constitution of the People's Republic of China, adopted on December 4, 1982, has been amended on several occasions in order to incorporate the regime's new objectives. ${ }^{6}$ Inspired to a large extent by the Soviet Constitution of 1936, China's founding document has evolved into a more modern-though completely hybrid-instrument. In 1999, the National People's Congress amended it in order to introduce the concept of a State governed by law (yifa zhiguo). Far from indicating the rule of law, however, the socialist "rule of law" in China's constitutional text still contains Marxist-Leninist precepts, Mao Zedong's thought, and the theories of Deng Xiaoping; overall, its objective is to strengthen the Chinese Communist Party's "ability to govern" (zhizheng nengli). The 2004 amendments managed to play on this ambiguity by partially recognizing the right to property, and by insisting on the role of the State in the "protection" of, and "respect" for, human rights.

However, the interference of the Party often results in confusing and contradictory laws of a de facto poor applicability, which are quickly exposed to a process of abrogation through disuse serving by default to moderate legislative excess. Difficulties in applying laws, a situation that has been consistently denounced by Chinese and foreign experts for at least 20 years, clearly represents the greatest impediment to any genuine desire for reform. The lack of uniform and just application of the law impacts directly on the establishment of a rule of law. This complex question has many facets, notably in relation to the enforcement of court decisions. It is particularly interesting today to note that Chinese authorities have undertaken several extensive campaigns in favour of a better implementation of law. But these campaigns are largely based on repression and have had widely diverse objectives ranging from ensuring respect for intellectual property, condemning actions resulting in pollution, banning some religious practices and illegal land

\footnotetext{
5 On constitutional reform and the influence of foreign paradigm, see Yu [6].

${ }^{6}$ Dowdle [7].

7 See "China's Legal System: New Developments, New Challenges," The China Quarterly 191 (September 2007).
} 
requisitions, to closing undesirable internet cafes. ${ }^{8}$ While these actions do not engage with the population in the same way, they share some of their most salient characteristics with former anti-corruption campaigns (strike hard or Yanda) or revolutionary movements to mobilise the masses (Yundong). This resemblance derives from the generalised use of a form of violence conceived as a legitimate capacity for restraint by the State, but against which ultimately there is no recourse. This view of the application of the law fails to promote acceptability of the legal system and its predictability; furthermore, it eventually contributes, as we will see below, to delegitimize the norms and the role of a justice system, which aspires to professionalism and independence.

Nevertheless, this is in this very context that a number of seminal developments in the creation of rights have taken place. At the centre of these developments of a particular "socialist rule of law", property and labour rights appear as some emblematic illustrations of the hopes and challenges of this unachieved legal reform and its inherent contradictions.

\subsection{Emerging Rights}

\subsubsection{Property Rights}

Of all areas of Chinese law, it is the process of rewriting civil law that most clearly highlights the contradictory forces at work in legal reforms that are torn between liberal leanings and the need to preserve an authoritarian socialist regime. How can one indeed reconcile the liberal-inspired drafting of a civil code, enshrining individual freedom and will, with respect for a "socialist market economy" that seeks to justify the arbitrary intervention of the State?" This fundamental question has quite naturally peppered the debates on a Chinese doctrine deeply divided between two schools of thought: one favoring legal transplants as a form of beneficial internationalisation, the other opposed to an acculturation that is unable to meet China's needs. ${ }^{10}$ It is by paying special attention to the debates within a community of increasingly better-trained jurists who are now well informed on the realities abroad, that one understands how the birth of a "civil society" has bolstered the work of these Chinese jurists seeking the emergence of a legal system distinct from the State. ${ }^{11}$ The technicalities of law, envisaged as a protecting shield and a powerful sword, seek in reality to encourage emancipation from the political power.

Such contradictions, which were already at work during the adoption of the 1999 contract law, re-emerged with unprecedented strength during the preliminary debate on the much vaunted Property Law that took effect on 1 October 2007. It was clear

\footnotetext{
8 This topic has been studied by van Rooij [8].

9 See the remarkable Ph.D. Dissertation of Jiayou [9].

10 See Piquet [10].

11 Whether a civil society could exist in a non-democratic regime is a question that deserves special developments. I will briefly address this issue at a later stage, but have chosen for now to use this term to suggest the emergence of organisations distinct from the State and revealing of the individual expectations of large segments of the Chinese society.
} 
since the end of the 1990s that the Chinese "New Left", which actually groups several movements, had been wielding real influence over political debate. ${ }^{12}$ However, it was the interventions in August 2005 by Gong Xiantian, a law professor at Beijing University that sparked lively comments from among jurists. Professor Gong-in fact, an isolated figure-was a firm Marxist whose main argument consisted in the unconstitutional nature of the protection of property rights. This would have remained anecdotal if Chinese authorities had not taken up the matter. Wu Bangguo, Chairman of the Standing Committee of the National People's Congress, was reported to have directly contacted Professor Gong, who then met Hu Kangsheng and Wang Shengming, Chairman and Vice-Chairman, respectively at the time, of the Legislative Affairs Commission of the NPC Standing Committee. All this led to yet another postponement of the bill and, most crucially, to its recasting in a mould more respectful of socialist constitutional imperatives. It should be noted that the passage of this law was achieved only at the end of a legislative saga that began in the early 1990s. A first draft had been presented in 2002 and was ameliorated after a fashion by the 2004 constitutional amendments that guaranteed private property. Complications began in July 2005 when a new draft was published with a view to gathering external comments. Almost 12,000 reactions similar to that of Professor Gong reached the Congress. Finally passed on 16 March 2007, and implemented on 1 October, the Property law, largely inspired by the German Civil Code, (Bürgerliches Gesetzbuch or BGB) but written in the context of a "socialist rule of law", has been complemented by a set of interpretative opinions to be issued by the Supreme People's Court. ${ }^{13}$ The complex structure of this 247 articles "Real Rights Law" demands detailed study, provision by provision. ${ }^{14}$ Some provisions clarify and obviously consolidate private property, but within the framework of a "socialist market economy" that gives precedence to State and collective property. ${ }^{15}$ Let us only cite, as a clear illustration, the article 3 of the 2007 "Real Rights Law" entitled "Ownership Elements in Socialist Market Economic System":

"During the primary stage of socialism, the State adheres to the basic economic system wherein public ownership is the principal element, and diversified ownership elements develop jointly.

The State solidifies and develops public ownership element, and encourages, supports and guides the development of non-public ownership economic elements.

The State adopts a socialist market economic system, and safeguards the equal legal standing and the development rights of all market subjects."

\footnotetext{
12 For an outline of the debate driving these currents see Hook [11]. For a portrait of Wang Hui, the figurehead of the "New Left", see for example Mishra [12].

13 Text available in Mandarin on the Lawinfo China website: http://www.lawinfochina.com/law/display. asp? $\mathrm{db}=1 \& \mathrm{id}=5920 \&$ keyword.

14 For the legal text translated, please see: http://www.lawinfochina.com/display.aspx?lib=law\&id=6642.

15 See Zhang [13]. See http://papers.ssrn.com/sol3/papers.cfm?abstract_id=1084363\&amp;partid= 593649\&amp;did=21491\&amp;eid=31304459 and Berkeley Business Law Journal, Vol. 5, 2008. See, as well, Eva Pils [14].
} 
In market economies of liberal inspiration, ownership is widely recognized as a fundamental right, which is therefore imprescriptible. In China, while property right is now acknowledged by the Constitution, its protection is not clearly established, as State property prevails and the justiciability of rights is not guaranteed.

Nevertheless, faced with injustices in relation to land grab, a movement of "rightful resistance" has gradually emerged. Famers, like many others Chinese citizens, are progressively getting aware of their rights and, encouraged by the dissemination of the concept of "juridicization" (fazhihua), try to believe in the effectiveness of these particular property rights now guaranteed not only by the Constitution, but also by the 2007 Real Rights Law. But again, how could we believe in the effective opposability of property rights if neither the Constitution, nor the 2007 law clearly recognizes the right to own land. The later, indeed, does not question two fundamental principles: the public nature of land ownership in urban areas and that of collective ownership in rural areas (article 47). In short, private ownership of land is never clearly provided. Rural residents have ownership of the produce of their land, but not of the land itself, which is collectively owned. Expropriation (zhengshou) is justified by the 2007 law (article 42) when the public interest (gonggongliyi) is clear and if a just compensation (xiangyingbuchang) is awarded. The ambiguity of the phrasing of the law as well as of the notion of "best interests" of the State to requisition land obviously leaves considerable discretion to local authorities hardly interested in giving just and equitable compensations to affected populations. The property law does not clarify an extremely complex legislative architecture that lies between civil and administrative law, national and local authorities. Finally, administrative recourses against these illegal expropriations and unfair compensations are extremely limited in scope and effects due to the problematic statute of a justice that is still very much linked to the interest of the local Party-State as we will see below. Interestingly, equally ambiguous legal reforms have taken place in the era of labour.

\subsubsection{Labour Law: Seizing Rights}

While acceptance of international standards and practices remains selective, ${ }^{16}$ and modernisation of Chinese employment rules also faces resistance from national and multinational enterprises as the debate on the passing of the 2008 new Labour Contract Law had showed, the internationalization of Chinese law has special and somehow positive effect on Chinese labor law and how these new rights have been seized by aggrieved workers.

Since the laws on labour and trade union came into force in $1995^{17}$ and 2002, Chinese workers have received theoretical protection and, although this may not yet

\footnotetext{
16 The selective nature of this internationalisation was pointed out several years ago by Pitman Potter. For a recent analysis of these trends and China's emergence on the international scene, see Potter [15].

17 The Labour Law, which came into effect on January 1995, still remains the foundation of China's modern labour system. It required all enterprises to sign employment contract with all-full time employees and grant these employees with a special rights-based protection vis-à-vis their employers on a wide range of issues such as working hours, overtime payments, health and safety at work and, very importantly, termination of contracts. Once again, the real issue has been the implementation of this quite complete set of norms.
} 
fully comply with international standards - China has only ratified four of the eight Fundamental Conventions of the International Labour Organisation (ILO) -,${ }^{18}$ this protection is not negligible. Several other rules and regulations adopted at the national and local level, such as the Law on Labour Security of 29 June 2002 and the Law on the Prevention and Treatment of Occupational Illnesses of 27 October 2001, represent real normative advances. However proclaiming rights does not necessarily guarantee their implementation. These rights lack guarantees since many extra-judicial factors prevent their application. The granting of labour rights, for instance, remains highly selective. Almost two-thirds of the population has yet to receive protection from labour rights set out in the 1995 Labour Law. It should also be noted that some categories of workers are inadequately protected and are indeed victims of abject discrimination, such as through the residence permit system (hukou) and job discrimination on the basis of sex or disability, among others. Lastly, forced labour is obviously the darkest area in this general picture. Obligatory or forced labour is banned almost universally. ILO Conventions 29 (1930) and 105 (1957) are the ones most countries adhere to. ${ }^{19}$ China has not ratified either convention and is in a highly ambiguous position: the State continues to engage in this form of exploitation, and refuses to take all the necessary measures to abolish their practices of "reform through labour" 20 (laogai or laodong gaizao) or "reeducation through labour" (laojiao or laodong jiaoyang) while condemning the crime of forced labour in private enterprises. Although the discussions of possible reform were revived when President Xi Jinping came to power, and a decision by the National People's Congress Standing Committee to formally abolish the 56-year-old system had eventually been taken in December 2013, some new manifestations of extrajudicial detention, including "black jails", drug rehabilitation facilities and "brainwashing centres" remain as illustrated by Amnesty International's investigations. ${ }^{21}$ Finally, and very importantly, the absence of independent union representation severely curbs Chinese workers' collective exercise of their fundamental rights and freedoms. ${ }^{22}$

However, workers organise themselves, and with the help of legal advisers coming from the nascent world of NGOs and private law firms, they formulate their claims against the businesses and local governments. Indeed, despite the absence of a complete democratization movement and without the unanimous support of

\footnotetext{
${ }^{18}$ See http://www.ilo.org/ilolex/english/docs/declworld.htm.

19 See http://www.ilo.org/ilolex/english/newratframeE.htm.

20 See http://www.ilo.org/ilolex/english/newratframeE.htm.

21 See Amnesty International, «China: Abolition of Labour Camps must lead to wider detention reform» http://www.amnesty.org/fr/node/44188.

22 While China has ratified the 1966 UN Covenant on Economic, Social and Cultural Rights in 2001, it has also made a clear reservation to the article 8 ("right of everyone to form trade unions and join the trade union of his choice"): " The application of Article 8.1 (a) of the Covenant to the People's Republic of China shall be consistent with the relevant provisions of the Constitution of the People's Republic of China, Trade Union Law of the People's Republic of China and Labor Law of the People's Republic of China".
} 
independent administrative and judicial institutions, ${ }^{23}$ a number of elements have nevertheless permitted the emergence of a unique Chinese collective litigation movement that demonstrates some similarities to Public Interest Litigation (PIL) and, to some extent, finds its inspiration in its American and Asian predecessors.

For the last 10 years or so, Chinese legal scholars and China watchers have been observing the birth, development and logical limitations of a rights-based and civil society-led movement using the law as well as existing judicial (and non-judicial) avenues as tools for social emancipation within the current constitutional and legal framework prevailing in China. Interestingly, this sinicization (Zhōngguóhuà) of PIL finds its roots and strength in the use of rights-based tools which are themselves powerfully reinforced by a language of rights largely disseminated by the mediaincluding official channels - and ambiguously tolerated by a State that is both generating and limiting rights. While this grassroots-led movement has involved a number of rights including property rights as we have seen, it is largely in the labour and environment law fields that China is developing its most interesting and, as we will see, debatable variation of a PIL system. In this context, a China specific PIL, which I have called a 'Rights Interest Litigation' (RIL), emerges. ${ }^{24}$ Indeed, legislation alone, even the most progressive kind, has not yet permitted the realization of socio-economic rights and other forces are at work, from rights conscious lawyers to rightful society, in the realization of these rights. As a matter of fact, Chinese human rights defenders - whether academics, professional lawyers, 'barefoot lawyers', or self-taught lawyers such as 'the representatives of the people' (gongmin daili) - have significantly gained influence since the second half of the 1990s. ${ }^{25}$ At the heart of this new generation of lawyers are a number of specialised practitioners who defend the rights of migrant workers and whose reputation has spread beyond the borders of China-these lawyers include, for example, Zhou Litai in Chongqing or Tong Lihua in Beijing. At the same time, encouraged by international donors programs and private foundations (Ford Foundation, American Bar Association, etc.) a number of 'associations' of lawyers have been put in place, for example, the Centre for Protection for the Rights of Disadvantaged Citizens at Wuhan University launched at the initiative of Wang Exiang and the Beijing Zhicheng Law Firm founded in 2008 by Tong Lihua. These "NGOs" echo other forms of organisations that are specially developed to fill the void left by social and economic reforms. Human rights NGOs representing countryside migrant workers, emerged in the early 2000s at the initiative of urban elite close to the government, have experienced tremendous growth in recent years. They are now present throughout the Chinese territory, particularly in the southern province of Guangdong despite many attempts to control them including the recent crackdowns and

\footnotetext{
${ }^{23}$ In their work on PIL in Asia, Po Jen Yap and Holing Lau identify three main engines for the development of PIL: 'democratization, transnational migration of norms and ideals, judicial recognition of courts institutional role in shaping public law discourse within their jurisdiction.' Yap and Lau, PIL in Asia, p. 2.

${ }^{24}$ See Choukroune [16] and Choukroune and Froissart [17].

25 See Zhang [18].
} 
new legislative attempt to limit foreign NGOs presence and other "Charities". ${ }^{26}$ In addition, Chinese media play a key role in diffusing the hopes and grievances of the workers at the national and international levels as exemplified by the 2010 Southern China labour strikes. Despite the real and almost infinite capacity of Beijing to arbitrarily deploy its net of repression, these pockets of freedom for public participation are conducive to human rights realisation as they make the collective workers struggle more visible and hence more difficult for a governing elite concerned with its popular legitimacy to disregard. In recent years indeed, the ability of Chinese citizens to assert their rights in court has clearly expanded. As in environmental PIL/RIL, the government's choice to support labour litigation is relatively easy to understand: the cases brought to court are often technical and do not directly question the government's political choices. If ever they do, they are based on the rights enshrined in the new labour laws and diffused by a language of rights the government and Chinese leaders themselves promote with the help of legal and judicial aid programs sponsored by local and international NGOs in cooperation with Chinese lawyers. ${ }^{27}$ Oriented towards the working class and not the poorest strata of the society, the RIL can also spill over its initial framework and foster new legal developments, hence participating in the protection of all citizens' rights. At the heart of this labour RIL, discrimination issues occupy a central place. For example, the case of hepatitis B victims shows the peculiar entanglement of different social and political actors as well as the hopes and limitations of Chinese RIL. With the support of a Chinese NGO, Yirenping, carriers of hepatitis B have brought to the courts a number of cases alleging discrimination in hiring practices. ${ }^{28}$ The 2003 case of Zhou Yichao and Zhang Xianchu, two carriers of hepatitis B and victims of employment discrimination, made a number of major media headlines, and a website was created to support their struggle and ultimately assist in the development of a legislative proposal. This public support challenged the government and drew its attention to the need to take seriously the social consequences of this disease, as nearly 10 per cent of the Chinese population carries the hepatitis B virus. Interestingly, the NGO Yirenping (Yi (益), Ren (仁) and Ping (平) respectively, benefit, benevolence and equality) has been behind almost all Hepatitis B discrimination cases brought before Chinese courts. Founded in 2006, this NGO is headquartered in Beijing and has brought more than a dozen cases of Hepatitis B discrimination to court in 2006, forty in 2007, seventy in 2008 and still a little more each year, until, in 2010, a case argued by Yirenping was recognised as one of the most important constitutional decisions of the reform era. ${ }^{29}$ Their strategy, as relayed by the official State media (Xinhua news agency, CCTV channel, the People's Daily, etc.), seeks to challenge as many lawyers as possible and convince them to support their cause. It organises numerous training sessions on issues of discrimination using the legal tools available in Chinese and international

\footnotetext{
26 On how China seems to get inspiration from Russia in cracking down on NGOs, see Famularo [19].

27 See Webster [20]. See also Simon [21].

28 'Yirenping's Case Ranked as Most Influential Constitutional Cases of 2010', Beijing Yirenping Centre, 27 December 2010. Available at: http://www.yirenping.org/english/topten.htm.

29 See, for example, Fu [22].
} 
law while sponsoring parallel academic conferences and seminars. This strategywhich combines advocacy, education, research and publishing activities in the mainstream media or on the web-was progressively accepted by the Chinese leadership, as many cases were won and victims of discrimination got compensated. These Hepatitis B RIL cases have also had a direct influence on the legislative process with (1) the adoption of the Law on the Protection of Employment in 2007; and (2) the adoption of a regulation of the Ministry of Health, Human Resources and Social Security in 2010 requiring Hepatitis B testing to be deleted from the list of mandatory measures to be taken for the recruitment of public servants.

Can we, however, generalise this positive experience with regard to today's outrageous crackdown on the very same NGO Yirenping and the adoption of a series of reactionary new policies ${ }^{30}$ ?! Indeed, the Chinese RIL illustrates as well as questions the justiciability of socio-economic rights in an authoritarian regime and in turn interrogates the true intent behind China's legal reforms and the real interest of the Chinese leadership in building a "State governed by law". ${ }^{31}$ In the absence of a genuine rule of law and independent judiciary, these collective victories, as promising as they are, may not systematically transform into more rights realisation. Thus, the justiciability of rights could legitimize a given regime, for a particular moment, more than it supports rights realisation.

\section{Rights Instrumentalization}

Despite the emergence and operationalization of a right discourse, in the area of socio economic rights in particular, the instrumental character of Chinese law is still very much present as demonstrated by the inherent limitations of the legal professions reforms including that of a the absence of an independent judiciary, which together prevent any evolution in favour of the rule of law and the genuine realization of rights.

\subsection{Rights Defenders Struggle}

The rehabilitation of the legal profession and its attempted separation from the State apparatus is yet an incomplete and deceiving process. Banned between 1957 and

\footnotetext{
30 In March 2015, Chinese police officers raided Yirenping office seizing laptops and details of contacts as a new example of crackdown on dissent, see: http://www.reuters.com/article/2015/03/26/us-chinarights-idUSKBNOMMOCD20150326. A series of similar crackdowns rapidly followed from March 2015 on and dozen of human rights lawyers have been targeted in a nationwide crackdown in early July 2015 with more than 200 lawyers and family members detained! See: "What's China crackdown on lawyers says about authorities fear of burgeoning rights defence movement": http://www.scmp.com/news/china/ policies-politics/article/1840611/heavy-hands-vs-power-words-china-cracks-down-fast.

31 Since February 2001, China has been a party to the International Covenant on Economic, Social and Cultural Rights (ICESCR) and as such the UN Committee has reviewed the implementation of its obligations under the ICESCR. See Choukroune [23]; and generally Choukroune [24]. A number of authors have investigated the politics and practices of courts in authoritarian regimes, hence providing a better view of the role of the judiciary in non-democratic countries. See, for example, Ginsburg and Moustafa [25].
} 
1977, lawyers were gradually allowed to participate in the legal system after the adoption of the 1978 Constitution and the new criminal rules of 1979, which restored the right to defence. Lawyers nevertheless remained "legal agents of the State", a type of official with special status, whose activities were fully overseen by public bodies. The "All China Lawyers Association" (ACLA) and its local branches have increasingly taken charge of managing these professionals. That hardly makes for their independence as they report to the justice ministry. The 1996, "Law on Lawyers and Legal Representation" was envisaged as a professional charter for a burgeoning profession. Lawyers finally had a right to work outside the State system and private firms mushroomed. However, a number of provisions tend to restrict freedom of action by Chinese human rights defenders. Article 96 of the Criminal Procedure Law stipulates that lawyers accused of divulging State secrets and who wish to seek outside help should first obtain permission from public security authorities. Even the concept of 'State secret' is defined so vaguely as to render rights defenders vulnerable to such accusations. Article 306 of the Criminal Procedure Law, widely used to silence lawyers, deems some actions criminal by equating them with fabrication of evidence or perjury. The text of the Law on Lawyers has undergone recent changes, but its direction and intention are unclear. ${ }^{32}$ See http://www.npc.gov.cn/zgrdw/common/zw.jsp?label=WXZLK\&id=373837\& pdmc $=110106$. From the case of the blind lawyer Chen Guangcheng, one of those "barefoot lawyers" who no longer hesitate to use a legal system that is tending to offer a modicum of protection in defending fellow citizens against the State's arbitrariness, to many other outrageous and repeated abuses on the new fangled human rights defenders (weiquan renshi) and self-taught jurists imbued with a passion for justice and sharing a fierce desire to challenge authorities on the strength of legal arguments, numerous recent examples of mistreatment and obvious denial of individual rights bring more questions than answers on the Chinese legal reform intentionality. ${ }^{33,34}$ What type of regime could be committing such gross violations of human rights and dignity so widely and with total impunity? A similar observation could be formulated in terms of judicial reform.

\subsection{Judicial Institutionalisation and Professionalization: A Failed Effort}

During the years of reform, the courts were reorganised according to a four-tier hierarchy, with the Supreme People's Court (Zuigao renmin fayuan) at the top. ${ }^{35}$

\footnotetext{
32 The lawyer law has been amended by the Standing Committee of the National People's Congress of the People's Republic of China on October 28, 2007. These revisions afford more protection for the attorney-client relationship, raise legal ethic standards, allow solo practice, but maintain some ambiguities on the lawyer professional liability and status.

33 For a brief account on the most prominent Chinese rights defenders now in jail, under house arrest or harassed by the Chinese State, see Human Rights Watch Snapshot available at: http://www.hrw.org/ Chinas-rights-defenders.

34 See the seminal work of Eva Pils [26].

35 There are three other levels: 30 High People's Courts (Gaoji renmin fayuan 高級人民法院), which have authority in provinces, autonomous regions and municipalities directly under the central government; 389 Intermediate People's Courts (Zhongji renmin fayuan 中級人民法院), which function at the prefecture level, with the municipalities catered for by courts at the level of provinces and
} 
There are 3,000 Basic People's Courts with approximately 200,000 judges. Their level of professionalism was enhanced considerably in 2002 with the establishment of the standard national exam, which has a success rate of around $10 \%$. Still the vast majority of practising judges has nevertheless had no real legal training. There is obviously a huge difference between a judge in the Supreme Court trained in legal issues in China and overseas, aware of international realities and of belonging to a community of jurists who are able to exercise true power to interpret the law and a judge drawn from the ranks of the army or the police, appointed by a local people's congress, and continually confronting problems of legitimacy vis-a-vis Party officials, as well as lacking resources and tempted by corruption. ${ }^{36}$

In 1999, at the pick of the legal reform agenda, the Supreme People's Court adopted a first five-year reform plan aimed at enhancing the professionalism and independence of judges. ${ }^{37}$ On 18 October 2001, the Court published a code of ethics, targeting in particular judicial corruption. ${ }^{38}$ In October 2005, the Court unveiled its second five-year plan (2006-2010), one of whose highlights was to implement a process of centralised national review of capital punishment sentences. ${ }^{39}$ Other plans followed including the latest attempt of July 2014 putting forward 45 reform measures. While it is a clever means of depoliticising the law by strengthening the powers of high-ranking judges, these reforms run the great risk of being very difficult to implement. Despite the commendable efforts of a Supreme Court made more dynamic through the profile of Xiao Yang as its President, the Party's interference remains too strong for the acclaimed modernisation to have real effect. ${ }^{40}$ On the opposite side of the Chinese legal scholars universe, we also find the quite unusual analysis of Randall Peerenboom who, in one of his latest articles, supports the idea of the many "common myths and unfounded assumptions" about the Chinese judicial system. A serious discussion of these arguments would require an entire article, but we can certainly manifest our strong disagreement over some of these supposedly unfounded assumptions: "The fifth assumption is that the lack of judicial independence is a serious problem in all types of cases in China. The sixth is that China's courts lack independence because independence is impossible within a single party State. The seventh, and a corollary, is that "the Party" is the main source of interference with the courts." See Peerenboom [31]. And what should we

Footnote 35 continued

autonomous regions; and, finally, more than 3,000 Basic People's Courts (Jiceng renmin fayuan 基層人 民法院), which have authority at the district and county level, and that are sometimes complemented by other People's Tribunals (Renmin fating 人民 法庭) in the instance of those counties that are geographically dispersed. Furthermore, there are more than a hundred specialist tribunals with authority in matters of fishing, maritime affairs, forestry, railways, etc.

${ }^{36}$ For a precise and rigorous history of the last 30 years of judicial reform, see Lubman [27].

37 Cf. Renmin Fayuan Wunian gaige Gangyao (Five-Year Program of Reform), http://www.dffy.com/ faguixiazai/xf/200511/20051128111114.htm.

38 See Li [28], http://chinaperspectives.revues.org/document274.html.

39 See Renmin Fayuan Dierge Wunian Gaige Gangyao (Second Five-Year Program of Reform), http:// www.dffy.com/faguixiazai/xf/200512/20051214221735.htm.

40 See Liebman [29, 30] “A populist threat to China's Courts" in Chinese Justice: civil dispute resolution in post-reform China, Mary Gallagher and Margaret Woo (eds.), 2009. 
think of the election, on March 16, 2008, a turning point, of Wang Shengjun as the New President of the Supreme Court? With no formal legal education, this native of Suzhou joined the Chinese Communist Party in 1972 and occupied various prestigious positions in the local communist apparatus until he became, in 1993, Deputy secretary general of the Party Central Politics and Law Committee. We observe, with both interest and concern, that Wang Shengjun was also Deputy director of the Central Committee for Comprehensive Management of Public Security from 2005 to 2008 and member of 15th Party Central Commission for Discipline Inspection. With this change of presidency, the Supreme Court had also modified its discourse to the great confusion and unhappiness of the many "modern" judges who were looking forward to the professionalization of a judiciary, which could eventually become independent from the Party-State. As stressed by Professor Jerome A. Cohen at the time in one of his many pertinent formula:

"In a series of mind-numbing ideological clichés, Mr. Wang emphasizes upholding party leadership and focusing the courts on economic development and social stability. For Mr. Wang (...) concerns for judicial fairness and justice must be interpreted in light of "Minyi", or "public opinion."41

Moreover, there is no institution equivalent to a kind of "high council for the judiciary", for example, and there is absolutely no guarantee either of the independence and impartiality of the judiciary under any statute. More specifically, the Standing Committee of the CPC Political Bureau is to be the body really in charge of justice, through the establishment of a coordinating group on judicial reform (sifa tizhi jizhi gaige). Through this group and the Party's discipline inspection commissions, the entire judiciary apparatus (prosecution, judges, ministry and even the police) is subject to the Party.

Clearly all this is a question of judicial independence. But how to assess this independence and what type of progress could be made in terms of fairness at a time when the new Supreme Court's President called, in typical political terms, for the "demystification" of the judicial process? As clearly shown by the Beijing based Professor He Weifang, a genuine demystification would require much more than what is proposed by the Chinese leadership, that is a final clarification of the applicable rules and transparency in courts proceedings. ${ }^{42}$ Recent developments are certainly not encouraging, rather they are revealing of the great leap backward of the Chinese Judiciary: in early 2015 indeed, the Supreme Court President Zhou Qiang clearly stated that the Court will "resolutely resist the influence of mistaken Western concepts and ways of thinking" ${ }^{43}$ In issuing this kind of peremptory and apparently definitive statements, the Courts is not only moving back to the darkest eras of the Maoist regime, but also evolving in-and somehow justifying-a complete schizophrenic environment. On 9 July 2014, the Supreme People's Court indeed issued its fourth five years reform plan stressing, amongst a number of clichés on the "construction of a socialist system of operations with Chinese characteristics", the

\footnotetext{
41 See Cohen [32].

42 See http://blog.sina.com.cn/s/blog_488663200100b3s7.html.

${ }^{43}$ See Josh [33].
} 
need the foster human rights protection and judicial transparency with a flexibility for operation at the local courts levels hence not only acknowledging the dysfunctional nature of the system, but also directly borrowing, as it has done for the past 30 years of reform, many so called "Western" concepts. ${ }^{44}$

This return to the past, embedded in multiple layers of political propaganda using national heroes as in the 2010 "Model Judge" campaign to penetrate the mind of the masses, does not only brings disappointment amongst the legal profession, but also real worries as to the future of an already quite uncertain judicial reform. ${ }^{45}$ In addition, and in a logical move against the law, the Party-State has constantly promoted the return to mediation in the context of a "harmonious society" (hexie shehui) deprived of conflicts and apparently relying on the Confucian ideal of a "world without litigation" (tianxia wusong). ${ }^{46}$

\subsection{The Return of Mediation: beyond the Response to Disillusionment with the Judiciary}

Escalating disputes and the relative inability of the justice system to resolve them have aroused disillusionment, in response to which Chinese authorities are indeed again promoting their classic tool, mediation, but now vested with the virtuous halo of socialist harmony.

Introduced into the legal studies courses in 1981 and into the compulsory curriculum only in 1986, Chinese administrative law is recent and still evolving. The much anticipated Administrative Procedure Law of 1989 marked a decisive turning point by allowing the public to take on the administration for any illegal acts. ${ }^{47}$ The 1994 Law on State Compensation, as well as the 1996 Law on Administrative Penalty, are part of this evolving framework. The public has not quite taken to this form of justice in droves, as only about $2 \%$ of cases pitted a citizen against an administration. ${ }^{48}$ Court access for those affected by an administrative decision seems to contradict the traditional and apparently unchanging socialist credo of "government of the people by the administration" (guan guan min). Authorities will have to take account progressively of modest efforts to make the administration accountable to the people (min gao guan). ${ }^{49}$ All

\footnotetext{
44 An outline of the plan is available in an English translation at: http://chinalawtranslate.com/en/courtreform-plan/.

45 On the "Model Judge" 2010 Campaign, See Minzner [34]. See as well, for a general overview, Yu [35, 36].

46 See Supreme People's Court Opinion on Further Increasing the Positive Role of Mediation (in Litigation) in Constructing Socialism and a Harmonious Society [Zui gao renmin fayuan guanyu jin yi bu fahui susong tiaojie zai goujian shehui zhuyi hexie shehui zhong jiji zuoyong de ruogan yijian], issued on 7 March 2007, available at http://www.chinacourt.org/flwk/show1.php?file_id=116688.

47 Cf. Potter [37]; Minxin Pei [38].

48 See for example Kevin O'Brien \& Lianjang Li, Suing the Local State: Administrative Litigation in Rural China, 51 The China Journal, (2004), pp. 75-96.

49 Heuser [39].
} 
these changes, deemed positive by some analysts, stem from an abiding desire to keep and strengthen social stability. ${ }^{50}$ The 1989 Administrative Procedure Law grants limited control of administrative actions. The courts can only control the legality of the norms, not their validity or reasonableness. Further, when an administrative tribunal finds that a legal rule conflicts with one of a higher organ, it has no power to invalidate the first rule, and at best can refuse to apply it, which happens but rarely. Only those in charge of producing laws may invalidate the wording of a law or administrative ruling.

Statement by Xiao Yang ${ }^{51}$ favouring administrative mediation (hejie) hardly foreshadow a real improvement to the system. Local courts have responded to the call by the Supreme People's Court former President by backing the proposal for letting cases be withdrawn in favour of non-judicial settlement. The cases in question seem to concern settlement of matters relating to "mass movements" (expropriation, restructuring of State enterprises, pollution, etc.). In such instances, the dispute is headed off to preserve the fiction of harmonious cohesion of a people bound by the common ideal of stability. The objective is clear but, meanwhile, a desperate struggle is under way to realize, as we have seen, a true reform of the judicial professions including rights of the defense.

\section{Rights Distrust}

How to interpret this return to the past and the many twists and turns of a Chinese legal reform generating competing legal cultures? While the syncretic, incoherent and incomplete nature of China's legal system no longer evokes surprise, the last "reforms" attempts are rather puzzling. ${ }^{52}$ What is truly Chinese in today's "socialist harmonious society" and its new developments in a "China dream" project for a country "ruled by law" while showing a new distrust towards Western values and eventually rights themselves? Confucius? Probably not. Irrespective of whether the Party-State invokes them or not, Confucian values do not seem to exert the influence often credited to them, even though such values are increasingly discernible in Chinese society at large. Without actually clarifying the ambiguities of their current discourse, Chinese leaders avoid all direct linkages to Confucian thought. ${ }^{53}$ On the contrary, they try desperately to find a common thread between their latest policies and Marxist doctrine. Hence the many references to the Manifesto of the Communist

\footnotetext{
${ }^{50}$ Heuser, Ibid. Most analysts do not share these conclusions, however, and remain cautious over the effectiveness of citizen protection in this much anticipated, yet disappointing bill. P. Potter for example speaks of an "elusive objective", linked to the bill's self-limiting character.

51 See http://www.court.gov.cn/news/bulletin/activity/200703300020.htm for a version in Mandarin.

52 On the hopes and limitations of the internationalization of Chinese law arising from the example of the WTO, see Choukroune [40]. For recent developments on the same and how China issues international economic law, see Choukroune [41].

53 In this context we share the view of Alice Miller, who believes that the socialist harmonious society is in the process of accommodating itself more readily to a return to the neo-Soviet language dear to $\mathrm{Hu}$ Jintao than to a genuine re-reading of Confucian thought, see Miller [42].
} 
Party and the repeated stress on the "core of socialist values". These are systematically laid out, linked to "China's past experiences," and are in fact summed up in Hu Jintao's eight "Honours and Disgraces". 54 In this search for socialist values with Chinese characteristics, the "hero" figure is again sanctified through the designation of "national moral models," 55 the new Lei Fengs of the modern era. ${ }^{56}$

Is this all designed mainly to stall for time? Reacting to criticisms from the "New Left" and to popular unrest, the "socialist harmonious society" had already adopted diversionary tactics, leading with seeming goodwill into a nowhere Utopia. ${ }^{57}$ This particularisation also allowed a troublesome political universal to be kept at bay as exemplified by China's ambiguous attitude towards international law and for example its non-ratification of the International Covenant on Civil and Political Rights which, if applied domestically, would result in far-reaching changes to current criminal law standards and-in not the least of its effects-render justiciable, both within China and externally, a number of fundamental rights. ${ }^{58}$

Meanwhile, as we have seen, the last ten or so years have witnessed an emerging legal culture that is unquestionably new-from young students' enthusiasm for the legal profession, television programmes denouncing corruption or injustices, the flourishing "literature on the legal system" (fazhi wenxue), the rising number of lawsuits, to even the relentless determination of workers or farmers to fight for their rights. Though considered during the revolutionary period to be harmful to the interests of the ruling class, law as a means of resolving social issues seems to be enjoying new-found respect by the people while the Chinese State now fears the consequences of its own normative creations. Seen in this light, "socialist harmonious society" as well as the newest attempts to "govern the society" according to a law itself instrumentalized and feared for its unpredictable effects when seized by the people appears, at first glance, as a softer version of something common to all totalitarian systems: the idea of the "One" or the "One People" ("Peuple Un") that is an harmonious society, freed of conflicts and divisions. Indeed, as the French philosopher Claude Lefort has shown:

\footnotetext{
54 See http://english.cpc.people.com.cn/66102/4933374.html.

55 See http://english.people.com.cn/90001/90776/6266474.html.

56 On the resurgence of the hero in political discourse at the end of the $1990 \mathrm{~s}$, see the fascinating article by Bonnin [43].

57 This is a reference to Thomas More's Utopia as a means of political and spiritual struggle.

58 See Leïla Choukroune, "Justiciability of Economic, Social and Cultural Rights", 19 Columbia Journal of Asian Law, (Spring-Fall 2005). By virtue of article 2 paragraph 3 of the International Covenant on Civil and Political Rights (1966). "Each State Party to the present Covenant undertakes:

"(a) To ensure that any person whose rights or freedoms as herein recognized are violated shall have an effective remedy, notwithstanding that the violation has been committed by persons acting in an official capacity;

"(b) To ensure that any person claiming such a remedy shall have his right thereto determined by competent judicial, administrative or legislative authorities, or by any other competent authority provided for by the legal system of the State, and to develop the possibilities of judicial remedy;

“(c) To ensure that the competent authorities shall enforce such remedies when granted."See www. ohchr.org/english/law/pdf/ccpr.pdf.
} 
"The whole totalitarian edifice rests on the fantasy of a society presumed to have overcome internal divisions. Everything is given over to the compulsion of producing unity, or rather the appearance of it. This compulsion is the real categorical imperative of totalitarian systems. (...) Now, totalitarian society has been, and continues to be, affected by democratic individualism. It is only intelligible against a background of democratic modernity." 59

But making such a comparison with totalitarian society is as tempting as it is misplaced. Today, it is rather farfetched to speak of totalitarian society in describing a country like China where, for example, individualism has never been so clear. This move towards another ethics is not immune of paradox: the new Chinese paradigm does not shy away from playing with fire as it uses the vocabulary of rights but giving it a different meaning.

\subsection{Law as Discipline}

Law in China today has become more than a mere alibi: it is the expression of the gap between a conflict-free society, the ideal dreamt up by the Party, and the individualism the people eagerly seek. Law is not a mere totalitarian instrument, but serves as the arena for playing out this tension, this contradiction between, on the one hand, the aspiration for individualism, and on the other hand, concerns about social cohesion under the party's watchful eyes. However imperfect it may be, the legal system is increasingly allowing the expression of this tension between a discourse of rights and the politics of law, if only because economic globalisation and the integration of China in the international society no longer affords any choice in the matter. In such a context, it seems, as I have previously argued, that the idea of discipline and disciplinary law is well attuned to current realities. ${ }^{60}$

\subsection{Disciplinary Law as Law}

First and foremost, disciplinary law defines itself as law. But it is the law of a partial society constitutive of a particular legal order. ${ }^{61}$ As shown by the legal philosopher Santi Romano in his book "L'ordinamento giuridico", any community feels "the

\footnotetext{
59 Cf. Poltier [44]. For an English language version of Claude Lefort's work, see, for example, CLAUdE LEForT, Complications, Communism and the Dilemmas of Democracy, supra note 3. Lefort draws upon Etienne de La Boétie's Discourse on Voluntary Servitude (1552-53), where subjects of the monarch or the tyrant "appeared ready to hand over their property, their parents, and themselves, captivated as they were by the image of the Prince or the name of the One (le seul nom d'Un)". See p.168. He then adapts these reflections to the Soviet power. "We return to La Boétie's subtle descriptions of the benefits that some people, and then a great number of them, draw from their enslavement. Among these benefits, one must count the power won by self-righteous minds to pose as master thinkers facing a mass of ignorant or irresolute people. (...) In short, one must always return to the interweaving (intrication) of power, law and knowledge in the party." See p. 171.

60 See Choukroune [45], available at http://www.germanlawjournal.com/index.php?pageID=11\&artID= 1429.

61 See for example, Corvilain [46]. See as well, Gérard et al. [47].
} 
absolute need for these internal disciplinary regulations". ${ }^{62}$ Being by nature the law of a group, disciplinary law is also considered as an autonomous set of norms, separated from both civil and penal legal orders. Thus disciplinary law appears as a kind of customary law, which is largely unwritten since there is no clear text containing an exhaustive list of offences that could lead to disciplinary sanctions that are at the discretion of the "judge". References made to it remain rather vague using the vocabulary of ethics as a kind of moral injunction. Individual rights do not prevail in those close communities, what prevails is discipline conceived as "negative legality". ${ }^{63}$ Disciplinary law stands beside the State as a law of private source that leaves ample room of interpretation to the entity responsible of its elaboration. European democracies had to wait for a series of decisions of the European court of Human rights for disciplinary law to be envisaged as part of "droit commun". 64 Those decisions where taken by the court in reference to the article 6 (right to a fair trial) of the European convention on Human Rights, which protects the independent and impartial character of a judicial decision while insisting on the need for publicity. Those fundamental principles were in clear contradiction with disciplinary law practices as the disciplinary "jurisdiction", which meets behind close doors, is generally made of members exercising the same profession as those who appear before it. With the König Case indeed, ${ }^{65}$ the

\footnotetext{
62 See Santi Romano [48].

63 Negative legality refers to a negative definition of infringements. All that is forbidden or is not allowed is alleged wrongdoing.

64 In remarkable collective book, Jean-Marc Trigeaud operates a fundamental distinction between "droit commun" and disciplinary law. See "Théorie de l'Etat et réalisme sociologique dans la pensée de Duguit et Hauriou" in Simone Goyard Fabre, [49]. «Encore faut-il distinguer entre droit commun et droit disciplinaire. Le droit disciplinaire dépend d'une institution, de l'organisation sociale qu'elle établit, tandis que le droit commun est le produit direct de la "sociabilité humaine", il émerge dans la société civile du fait des relations des groupes entre eux (familles, communes, professions)».

65 Cf. König v. Germany Case, European Court of Human Rights June 28, 1978. It this case, the applicant, a German national, had taken up practice as en ear, nose and throat specialist in 1949. In 1960, he opened, in Germany, a private clinic of which he was the owner and only medical practitioner. He performed plastic surgery. In October 1962, proceedings against Dr. König were instituted by the Regional Medical Society before the Tribunal for Medical Profession attached to the Frankfurt Administrative Court. He was declared unfit to practice in July 1964 and had his authorization to run his clinic withdrawn in 1967, and then, in 1971 his authorization to practice. Moreover, criminal proceedings were taken against him in 1972 for illegal practice of medicine. Different actions brought by Dr. König to challenge these decisions were in progress before the competent administrative court since November 1967 and October 1971, respectively. The applicant complained of the length of the proceedings taken by him against the withdrawal of his authorizations. The European Court of Human Rights hold that article 6 of the European Convention on Human Rights was applicable to the proceedings relative to the withdrawal of the applicant's authorizations.
}

Article 6 of the European Convention on Human Rights reads as follow: "Right to a fair trial"

" 1 In the determination of his civil rights and obligations or of any criminal

charge against him, everyone is entitled to a fair and public hearing

within a reasonable time by an independent and impartial tribunal

established by law. Judgment shall be pronounced publicly but the press

and public may be excluded from all or part of the trial in the interests of morals, public order or national security in a democratic society, where the interests of juveniles or the protection of the private life of the parties so require, or to the extent strictly necessary in the opinion of the court 
European Court of Human Rights somehow replaces disciplinary law under the banner of the rule of law.

\subsection{Disciplinary Law as Social Stabilizer}

Then how do the differences between disciplinary law and liberal (individual) law appear in concrete terms? It is through government/State/Party-State functions going unopposed, primarily. Disciplinary law is a legal system in the leader's hands. Then, disciplinary norms, as we have seen before, only make sense in closed communities, such as those of a professional, family, sporting, or religious nature, wherein relationships are necessarily asymmetrical and whose raison d'etre lies outside the reach of law. They are predicated on an unquestioned purpose, which motivates their very presence. This is so because such groups are always in fact subgroups. At stake is only a part of something larger: neither school nor business engages a person's life in its entirety but only in part. In this regard, the analysis could get closer to Foucault's idea of "institution disciplinaire" ${ }^{66}$ This phrase has been developed by the French philosopher to conceptualize a set of similar places (prison, psychiatric hospital, army, etc.) where the discipline creates "docile bodies", perfectly suited to the modern industrial age. While attempting to control their members, disciplinary institutions must be able to constantly observe and record "docile bodies" as well as to internalize the whole process. Foucault's main critique against this peculiar form of power is based on a strict denunciation of the hidden agenda lying behind an apparently noble task, that of social rehabilitation. But the main reason why this approach differs from Foucault is that the paradigm, and its application to the Chinese "socialist harmonious society" or today's China's dream society, is relatively clearly visible and goes beyond a very restricted community in applying to the entire population, by specialized pockets, but entirely, to the society as whole. This creates a type of sui generis disciplinary law that goes far beyond its natural borders and seeks to preserve the cohesion of the society as well as its external image. As such, disciplinary law appears as a powerful social stabilizer that contrasts with liberal or individualist law. In this context, law should never play the role of a destabilizing power. It may limit or even control the

\footnotetext{
Footnote 65 continued

in special circumstances where publicity would prejudice the interests of justice.

2 Everyone charged with a criminal offence shall be presumed innocent until proved guilty according to law.

3 Everyone charged with a criminal offence has the following minimum rights:

a to be informed promptly, in a language which he understands and in detail, of the nature and cause of the accusation against him; b to have adequate time and facilities for the preparation of his defense;".
}

See http://www.echr.coe.int/ECHR/EN/Header/Basic+Texts/Basic+Texts/The+European+Convention + on+Human+Rights + and + its + Protocols/.

66 See notably, Foucault [50]. 
leadership (example of the Judiciary) to some extent at least, but will never challenge its legitimacy, the foundations of its very existence as reminded by the recent " $\mathrm{CCP}$ Central Committee Decision on Some Major Questions in Comprehensively Promoting Governing the Country According to Law". From this perspective, what is essential is to ensure the cohesion of the group and not really to guarantee people's individual rights. Disciplinary law or what we could now name in our Chinese context "stabilizing law" is not overtly opposed to them, but individual rights are treated as secondary. What matters most is protecting the smooth working of society as a whole and the regime's survival. Lastly, disciplinary/stabilizing law brings no universal claims. It limits itself to the border of the community, in this case the Chinese society within and without China. Lastly, what is fundamental is to uphold the authority of the State and its apparatus. In this regard, I share the analysis of Yu Xingzhong on what he describes as "State Legalism":

"Under the framework of State legalism, law is neither stable nor predictable; government policies prevail over, and sometimes even replace, laws. (...) Furthermore, the legislation-centered approach of State legalism puts judicial and legal enforcement institutions in subordinate positions. Meanwhile, the judicial system is defined as part of the State machine and treated like any other administrative organ, in which the judge is not a neutral adjudicator but a single link in the entire national chain and carries the same responsibility as administrators and legislators." 67

But how long could this rather fragile "stability by law" last? Isn't it highly possible that this paradigm might soon crumble under the weigh of the social expectations of fairness and equity instilled by the Party itself in the people's mind?

\section{Conclusion: "Stabilizing Law" as a Last Ditch Struggle}

\section{The train runs to the concentration camp} over my body, sobbing,

but I could not reach your hand

A poem from Liao Yiwu, wife of the jailed Nobel Price winner Liu Xiaobo ${ }^{68}$

There are indeed paradoxical trends emerging out of today's great divide between the Chinese people and the State. On the one hand, it is difficult to believe that the legal seeds, which have grown in a Chinese society eagerly seeking for its individual autonomization could bear no fruit. Ordinary life and business transactions are conducted according to the law, a law that is not deprived of the many flaws we have addressed in the above developments and still depends on the arbitrariness of the Party-State, but law. In addition, China, as global player, is using international norms in a rather non-confrontational way and without even

\footnotetext{
67 See Yu [51].

68 See http://www.theguardian.com/commentisfree/2014/jan/15/liu-xiaobo-china-nobel-prize-prisonwife-liu-xia-mistreat.
} 
questioning the nature and political ambitions of international law as if it de facto adheres to this body of norms. All these evolutions in favour of the integration of alien ("Western") rules and practices in an era of globalization cannot but produce deep and long lasting changes in the Chinese regime. The PRC is no longer a country without law or legal consciousness. A sui generis legal culture has formed while citizens have integrated the discourse of rights promoted for the past 30 years by the State. As a consequence, the recent initiatives in favour of the control of legal education or legal practice are not taken seriously by the Chinese citizens themselves who, at best, feign compliance, and often rebel in using a language of rights, eventually forming an alternative political discourse, in many as courageous as desperate applications ${ }^{69,70,71}$ On the other hand however, the Chinese State is still very much able to deploy its net of repression and negate its own legal creations for the sake of the "hyper stability" described by the Chinese intellectual Jin Guanto as a major feature of feudal China and which seems to have crossed the ages of Chinese politics. $^{72}$

These tensions between a language of rights now fully integrated by the Chinese citizens and the politics of law are exemplified by the latest massive and so unprecedented, as systematic, crackdown on Chinese human rights defenders. What was Hong Lei, the spokesman for the Ministry of Foreign Affairs attempting to create, in April 2015, when he declared that the NGO Yirenping was 'suspected of being involved in illegal activities and will be punished'? The legality he alludes to is not that of a rights based society at the centre of which human rights and, for instance, the presumption of innocence would be placed, but rather a political endeavour resting upon the use of law as a powerful social stabilizer and, when need be, a project able to put aside the individual rights the State has itself created and is supposed to guarantee. Be it arbitrary or "illegal", the Party can always resort to its sophisticated political control apparatus. "People, bear this in mind!" This is what is said to the world when 200 lawyers and their families' members are arrested in about 20 different cities. ${ }^{73}$ As we have seen above, the political objective is unambiguous: to preserve the fiction of the harmonious cohesion of a people bound by a common ideal of stability. But, meanwhile, a desperate struggle is under way, that of a competing legal culture promoted by a language of rights now deeply embedded in the Chinese society. Hence the Chinese government's reaction may appear as a last ditch struggle against the Party's own creation, a fight to discipline

\footnotetext{
${ }^{69}$ On legal education, see Minzner, Carl F. [52]. Available at SSRN: http://ssrn.com/abstract=2128151 or doi: $10.2139 / \mathrm{ssrn} .2128151$.

70 See for example the February 10, 2015 initiative of 9 lawyers entitled "By Its Nature Learning Should Be Open, To Seal Up Schools and Shut Up the Country is to Endanger the Nation. See: http://blog. feichangdao.com/2015/02/state-media-deploys-blogger-to-counter.html.

71 On the formation of an alternative Chinese political discourse and its fascinating lexicon and the way it may become viral on the net, see "The Grass Mud Horse Lexicon" at: http://chinadigitaltimes.net/space/ The_Grass-Mud_Horse_Lexicon.

72 See Jin [53].

73 See "What's China crackdown on lawyers says about authorities fear of burgeoning rights defence movement", op.cit., footnote 32 .
} 
the society and stabilize the regime by law, but an ultimate battle the State might not win against its people.

Open Access This article is distributed under the terms of the Creative Commons Attribution 4.0 International License (http://creativecommons.org/licenses/by/4.0/), which permits unrestricted use, distribution, and reproduction in any medium, provided you give appropriate credit to the original author(s) and the source, provide a link to the Creative Commons license, and indicate if changes were made.

\section{References}

1. China Labour Bulletin. 2014. Workers voices. Calling the union to account: One woman's decade of labour activism. http://www.clb.org.hk/en/content/calling-union-account-one-woman's-decade-labouractivism.

2. Lubman, Stanley. 2013. Document No .9: The party attacks western democratic ideals. China Real Time, The Wall Street Journal, 27 August 2013. http://blogs.wsj.com/chinarealtime/2013/08/27/ document-no-9-the-party-attacks-western-democratic-ideals/.

3. The China Quarterly's special issue on China's Legal System, vol. 191, September 2007.

4. Lubman, Stanley B. and Leila Choukroune. 2004. L'incomplète réforme par le droit [Incomplete reform through law], Esprit, February 2004.

5. Chen, Jianfu, Yuwen Li, Jan Michiel Otto, and Maurice V. Polak (eds.). 2000. Law-making in the People's Republic of China. Leiden: Brill.

6. Yu, Xingzhong. 2009. Western constitutional ideas and constitutional discourse in China, 19782005. In Building constitutionalism in China, ed. Stéphanie Balme, and Michael W. Dowdle, 111124. London: Palgrave Mac Millan.

7. Dowdle, Michael William. 2002. Of parliaments, pragmatism, and the dynamics of constitutional developments: The curious case of China. New York University Journal of International Law and Politics 35: 1-200.

8. van Rooij, Benjamin. and was already introduced in China's war on graft: politico-legal campaigns against corruption in China and their similarities to the legal reactions to crisis in the U.S. Pacific Rim Law and Policy Journal, pp. 289-336.

9. Jiayou, Shi. 2006. La Codification du droit civil chinois au regard de l'expérience français, [Codification of Chinese civil law in the light of the French experience]. L.G.D.J.

10. Piquet, Hélène. 2005. La Chine au carrefour des traditions juridiques [China at the crossroads of legal tradition]. Bruylant.

11. Hook, Leslie. 2007. The rise of China's new left. Far Eastern Economic Review.

12. Mishra, Pankaj. 2006. China's new leftist. New York: New York Times.

13. Zhang, Mo. From public to private: the newly enacted Chinese property law and the protection of property rights in China. Temple University, Legal Studies Research Papers Series, January, 212008.

14. Eva Pils. 2009. Chinese property law as an image of PRC history. Hong Kong Law Journal 39: 595611.

15. Potter, Pitman. 2007. China and the international legal system: Challenges of participation. The China Quarterly 191: 699-715.

16. Choukroune, Leila. 2015. The paradox of justiciability: labour rights litigation and realisation in China and India. In Socio-economic rights in emerging free markets: Comparative insights from India and China, ed. Surya Deva. London: Routledge.

17. Choukroune, Leilla and Froissart, Choé. 2013. Legal Reforms and Social Protest in a State with No Rule of Law: The Chinese Experiments, et Leila Choukroune, Chloé Froissart, " Réforme du droit et contestation sociale sans État de droit : le laboratoire chinois ", Le Mouvement Social 3/2013 244:4765.

18. Zhang, Y. 2006. Law and Labour in Post-Mao China. In Debating Political Reform in China: Rule of Law Vs. Democratization, ed. S. Zhao, Armonk: M.E. Sharpe, p. 180; and Gallagher, "'Use the Law as Your Weapon!"’.

19. Famularo, Julia. 2015. The China-Russia NGO crackdown. The Diplomat, 23 February 2015. http:// thediplomat.com/2015/02/the-china-russia-ngo-crackdown/. 
20. Webster, T. 2011. Ambivalence and activism: Employment discrimination in China. Vanderbilt Journal of Transnational Law 44: 643.

21. Simon, Karla. 2013. Civil society in China: The legal framework from ancient times to the "new reform era". New York: Oxford University Press.

22. Fu, Hualing, Embedded socio-legal activism in China: the Case of Yirenping, University of Hong Kong Faculty of Law Research Paper No. 2012/029. http://papers.ssrn.com/sol3/papers.cfm? abstract_id=2096998\#\#.

23. Choukroune, Leila. 2005. Justiciability of economic, social, and cultural rights: The UN committee on economic, social and cultural rights' review of china's first implementation of the international covenant on economic, social and cultural rights. Columbia Journal of Asian Law 19: 1-30.

24. Choukroune, Leilla. 2015. Socio-economic rights litigation and Chinese labour law reform, justiciability and authoritarianism. In China's influence on non-trade concerns in international economic law, ed. P. Farah. Farnham: Ashgate Publishing.

25. Ginsburg, T., and T. Moustafa. 2008. Rule by law: The politics of courts in authoritarian regimes. New York: Cambridge University Press.

26. Eva Pils and her recent book in particular, China's Human Rights Lawyers, Advocacy and Resistance, Routledge 2015.

27. Lubman, Stanley. 1999. Bird in a cage. Legal reform in China after Mao. Redwood City: Stanford University Press.

28. Li, Yuwen. 2003. Professional ethics of Chinese judges, a rising issues in the landscape of judicial practice. China Perspectives, May-June 2003.

29. Liebman, Benjamin L. 2007. China's courts: Restricted reform. Columbia Journal of Asian Law, 21 (Fall).

30. Liebman, Benjamin L. 2009. A populist threat to China's Courts. In Chinese justice: Civil dispute resolution in post-reform China, eds. Mary Gallagher \& Margaret Woo

31. Peerenboom, Randall. 2008. Judicial independence in China: common myths and unfounded assumptions. La Trobe Law School Legal Studies Research Paper, No. 2008/1. http://papers.ssrn.com/ sol3/papers.cfm?abstract_id=1283179.

32. Cohen, Jerome A. 2008. Body blow for the judiciary, South China Morning Post October 18, 2008. http://www.scmp.com/portal/site/SCMP/menuitem.2af62ecb329d3d7733492d9253a0a0a0/?vgnextoid= 6efb72965ea0d110VgnVCM100000360a0a0aRCRD\&ss=China\&s=News.

33. Josh Chin. Don't call it Western: China's top court unveils vision of reform. The Wall Street Journal, http://blogs.wsj.com/chinarealtime/2015/02/26/dont-call-it-western-chinas-top-court-unveils-visionfor-reform/.

34. Minzner, Carl F. 2011. China's turn against law. The American Journal of Comparative Law 59: 935983.

35. Yu, Xingzhong. 2010. Judicial professionalism in China: From discourse to reality. In Prospects for professionalism in China: Essays on civic vocations, ed. William P. Alford, Kenneth Winston, and William C. Kirby, 78-108. London: Routledge.

36. Yu, Xingzhong. 2013. Academic discourse, official ideology, and institutional metamorphosis: reflections on contemporary Chinese legal discourses and reality. In Culture and social transformations: Theoretical framework and Chinese context, ed. Tianyu Cao, Xueping Zhong, Liao Kebin, and Ban Wang, 153-165. Leiden: Brill.

37. Potter, Pitman B. 1994. The administrative litigation law of the PRC: Judicial review and bureaucratic reform. In Domestic law reforms in post-mao China, ed. Pitman B. Potter, 270-304. New York: M.E. Sharpe.

38. Minxin Pei. 1997. Citizens v. Mandarins: Administrative litigation in China. The China Quarterly 152: 832-862.

39. Heuser, Robert. 2003. "Le rôle des tribunaux administratifs dans la résolution des litiges entre la société et le gouvernement chinois" ["The role of administrative courts in resolving disputes between society and the Chinese government"], Perspectives chinoises.

40. Choukroune, Leila. 2007. The Accession of China to the WTO and Legal reform: is China heading towards a rule of law through internationalization without democracy? In La Chine et la démocratie [China and Democracy], ed. Mireille Delmas-Marty, and Will Pierre-Etienne, 617-661. Paris: Fayard.

41. Choukroune, Leila. 2014. Les BRICS et le droit international du commerce et des investissements. In Les dérèglements économiques internationaux, crise du droit ou droit des crises, ed. H. Gherari, 206229. Paris: Pedone. 
42. Miller, Alice. 2007. Hu Jintao and the sixth Plenum. China Leadership Monitor 20: 1-12. http:// www.hoover.org/publications/clm/issues/6301112.html.

43. Bonnin, Michel. 1996. When the Saints come marching back. China Perspectives 5: 10-19.

44. Poltier, Hugues. 1997. Claude Lefort. La découverte de la politique [Claude Lefort. The discovery of politics], 91-92. Paris: Michalon.

45. Choukroune, Leila. 2012. Global "Harmonious Society" and the Law China's legal vision in perspective. German Law Journal 13: 497-510.

46. Corvilain, Pierre. Le droit disciplinaire des ordres professionnels (Larcier. 11/2004).

47. Gérard, Ph. et al. 1983. Fonction de juger et pouvoir judiciaire, transformations et déplacements. Publications des Facultés Universitaires de Saint Louis.

48. Santi Romano. 1975. L'ordre juridique (original title L'ordinamento giuridico) French translation. Dalloz, p. 92.

49. Goyard Fabre, Simone. 2004. L'Etat au XXème siècle, regards sur la pensée juridique et politique du monde occidental. Paris: Librairie Philosophique Vrin.

50. Foucault, Michel. 2006. Discipline and punish, The birth of the prison Peguin.

51. Yu, Xingzhong. 2014. State legalism and the public/private divide in chinese legal development. Theoretical Inquiries in Law 15(1): 27-52.

52. Minzner, Carl F. 2013. The rise and fall of Chinese legal education (August 8, 2012). Fordham International Law Journal 36(2).

53. Jin, Guantao. 2001. Interpreting modern Chines history through the theory of ultrastable systems. In Gloria Davies (ed.), Voicing concerns: Contemporary Chinese critical inquiry (trans: Davies, Gloria), 157-183. Lanham, MD: Rowman and Littlefield. 